Pak. j. sci. ind. res. Ser. A: phys. sci. 2016 59(2) 96-108

\title{
Modeling the Land Suitability using GIS and AHP for Cotton Cultivation in Punjab, Pakistan
}

\author{
Nabila $\mathrm{Naz}^{\mathrm{a}}$ and Haroon Rasheed ${ }^{\mathrm{b} *}$ \\ ${ }^{a}$ Department of Computer and Software Engineering, Bahria University, Karachi Campus 13, \\ National Stadium Road, Karachi-75260, Pakistan \\ ${ }^{b}$ Department of Electrical Engineering, Bahria University, Karachi Campus 13, \\ National Stadium Road, Karachi-75260, Pakistan
}

(received October 29, 2014; revised September 10, 2015; accepted October 19, 2015)

\begin{abstract}
The main goal of this research was to establish a spatial model for identification of suitable land for cotton in Punjab, Pakistan through evaluation of multidisciplinary variables by applying geographic information system (GIS) and analytical hierarchy process (AHP) approach. In this model, rivers were used as constraint and seven factors were temperature, soil physical and chemical properties, soil $\mathrm{pH}$, aridity classes, agro-ecological zones, and river command area. On the basis of these parameters suitability maps were generated. By pair-wise comparison matrix (PWCM) of AHP, weights were extracted by means of principal Eigen vector by Saaty's method, with accepted consistency ratio of 0.09 . Multi-criteria evaluation (MCE) employing weighted linear combination aggregates all suitability maps to generate final suitability map. It was found that more potential sites exist along with existing cotton practiced area. The result provided important information for farmers to establish linkage between policy decisions and regulatory actions and to improve agricultural land management.
\end{abstract}

Keywords: cotton, multi criteria evaluation, analytic hierarchy process, land suitability, geographic information systems, pair-wise comparison matrix

\section{Introduction}

Cotton is Pakistan's main cash crop and is planted on $15 \%$ of its total arable land during the Kharif season. This production is concentrated in two provinces with Punjab accounting for nearly $75 \%$ and Sindh nearly $25 \%$ of this arable land. An estimated 1.6 million farmers grow cotton in Pakistan. The textile sector is the largest industrial sector in Pakistan and accounts for about 40\% of the industrial labour force (Shafiq-ur-Rehman, 2015). Pakistan is the $4^{\text {th }}$ largest producer, $7^{\text {th }}$ largest consumer, $7^{\text {th }}$ largest importer, and $12^{\text {th }}$ largest exporter of cotton in the world (FAS-USDA, 2015).

As a semi-industrialized country, Pakistan is heavily dependent on the agricultural crops such as cotton. As a result, the policymakers are facing a great challenge to carry out agricultural reform for sustainability and optimization of resources. To meet the increasing demand of agri-products, it is not feasible to bring more area under cultivation due to limited resources. To tackle this, focus has shifted from extensive to intensive farming for precision farming and sustainable agriculture (Perveen et al., 2013). To deal with the complexities for selecting

\footnotetext{
*Author for correspondence;

E-mail: haroon.rasheed@bimcs.edu.pk
}

the best location for agricultural production, necessitate the use of geo-spatial domain which accelerates the rate of adoption of sustainable agriculture and benefit the farmers and decision makers in agriculture planning (Joshua et al., 2013).

One of the most important applications of GIS is the display and analysis of data for environmental decisionmaking (Eastman, 1999). GIS-based MCDA combines and transforms spatial and aspatial data (input) into a resultant decision (output) (Malczewski, 2004). The hierarchical model i.e., analytical hierarchy process (AHP) consists of objectives, criteria and sub-criteria. To evaluate the criteria, scoring was made with preference scale, and a pair-wise comparison matrix (PWCM) was created, for which consistency should be below 0.10 (Akinci et al., 2013). Multi-criteria evaluation (MCE) model finds solutions to decision-making problems characterized by multiple factors, and weighted linear combination (WLC) aggregate them into a final land suitability index (Khoi and Murayama, 2010).

Using GIS based MCE model, cotton land suitability in Sindh, Pakistan was evaluated by agro-informatics data of soil, ground water availability, irrigation methods, climate, land use, cropping patterns and agro-ecological 
zones (Perveen et al., 2013). For the delineation of suitable soil for Zero-Till Wheat cultivation in Gujranwala, Pakistan based on soil profile, ground water survey data and satellite imagery was employed with GIS framework using weighted overlay (Iqbal and Mehdi, 2008). To achieve the goal of land suitability assessment in Sheikhupura and Nankana Sahib Districts of Punjab, Pakistan, GIS based AHP model was employed by using factors of soil texture and water supply along with other factors for production of rice (Waqar et al., 2013). Delineation of land suitability for agricultural production was employed by applying GIS based AHP approach in Yusufeli district of Artvin city, Turkey, using soil, land use capability class, land use capability sub-class, soil depth, slope, aspect, elevation, and erosion degree to identify highly, moderately, marginally and unsuitable areas (Akinci et al., 2013). GIS and MCDA model using AHP technique employed for suitable agricultural land in Greater Karu, Nasarawa state, Nigeria using soil, slope, water bodies and geological maps to indicate highly, moderately and not suitable areas (Joshua et al., 2013). For the identification of suitable areas for cropland in the Tam Dao National Park region, Vietnam, a GISbased MCE model using biophysical factors and Landsat ETM+ imagery indicated the location and extent of crop farming areas at different suitability levels (Khoi and Murayama, 2010).

The main research problem was the cotton requirements and limited cotton cultivation in the study area. Also a constant growth in Pakistani yarn exports was observed from 2009-2013 (Hussain, 2014). This research aims to identify suitable land for cotton cultivation in Punjab, Pakistan using the GIS based AHP modeling. It starts from geometric correction, digitization of the re-sampled maps to form the vector layers, then rasterization for all the factors and constraint was performed. After standardizing the maps for suitability, AHP was applied to weight the factors using Saaty's PWCM for suitability analysis. Finally, the MCE technique was applied using WLC for all the factors and constraints, to decide the land suitability for cotton cultivation in the study area.

\section{Materials and Methods}

Site description. Punjab is the second largest province of Pakistan in terms of land area at $205,344 \mathrm{~km}^{2}$ with coordinate extending from $27^{\circ} 42^{\prime} 20.16^{\prime \prime} \mathrm{N}$ to $34^{\circ} 00^{\prime}$ $59.04^{\prime \prime} \mathrm{N}$ latitude and from $69^{\circ} 20^{\prime} 6^{\prime \prime} \mathrm{E}$ to $75^{\circ} 22^{\prime} 49.44^{\prime \prime}$ E longitude. The province is bordered by Kashmir to the north-east, the Indian states of Punjab and Rajasthan to the east, Sindh to the south, Balochistan to the southwest, and Khyber Pakhtunkhwa to the west and Islamabad to the north. Temperature ranges from $-2^{\circ}-$ $45^{\circ} \mathrm{C}$. Climatically, Punjab has three major seasons namely; hot weather (April to June); rainy season (July to September); mild weather (October to March). Six rivers of Punjab named Indus, Jhelum, Beas, Chenab, Ravi and Sutlej provide heavy irrigation system by canals throughout the province. The province is mainly a fertile region along the river valleys. The region contains Thal and Cholistan deserts. Despite of its tropical wet and dry climate, extensive irrigation makes it a rich agricultural region. Wheat and cotton are the major crops. Cotton and rice are important cash crops (Saif, 2014).

Criteria for cotton cultivation. In the study area, cotton is sown in May or June and picking starts in September or October. The data source (Table 1) describes the source for obtaining all the factors and constraint utilized for evaluating the cotton land suitability. The suitable criteria (Arain et al., 2014) for cotton cultivation was characterized by the factors: canal command area; soil $\mathrm{pH}$ (6.6-8.4); soil chemical properties classes (Acid soils: slightly acid, neutral soils: non-calcareous to slight calcareous, mildly alkaline soils: non-calcareous to strongly calcareous, moderately alkaline soils: noncalcareous to strongly calcareous); mean maximum annual temperature $\left(34^{\circ} \mathrm{C}\right)$; soil physical properties

Table 1. Data source for the research work

\begin{tabular}{|c|c|}
\hline Data & Source \\
\hline $\begin{array}{l}\text { Statistical data for cotton production } \\
\text { for Punjab and } \\
\text { Statistical data for area sown under } \\
\text { Cotton for Punjab. }\end{array}$ & (Rafique, 2013) \\
\hline $\begin{array}{l}\text { Digital scanned map of Punjab rivers, } \\
\text { Digital scanned map of soil physical } \\
\text { properties, } \\
\text { Digital scanned map of soil } \mathrm{pH} \text { and } \\
\text { Digital scanned map of soil chemical } \\
\text { properties. }\end{array}$ & (Panagos et al., 2011) \\
\hline $\begin{array}{l}\text { Shape file of mean maximum annual } \\
\text { temperature. }\end{array}$ & (ICIMOD, 2008) \\
\hline Digital map of canal command area. & (Brabben, 2000) \\
\hline $\begin{array}{l}\text { Shape file of Punjab administrative } \\
\text { boundary. }\end{array}$ & $(\mathrm{PCO}, 2013)$ \\
\hline $\begin{array}{l}\text { Digital map of aridity classes and } \\
\text { Digital map of agro-ecological zones. }\end{array}$ & (PARC, 2007) \\
\hline
\end{tabular}


classes (River plain and terraces:non-calcareous and calcareous loamy soils); aridity classes (Arid (Kharif, Rabi) and Arid (Kharif), Hyper-arid (Rabi); agroecological zones (irrigated plains-D.G. Khan irrigated and irrigated plains-cotton zone). Rivers were used as constraint. The detailed description of suitability (Table 2) for factors and constraint describes both suitable and not suitable criteria for cotton cultivation (Arain et al., 2014). These values were in agreement with those considered in the literature.

Developing GIS based AHP model. For cotton land suitability, GIS-based AHP model (Fig. 1) describes all the steps used in this study. The geometric rectification of the downloaded digital scanned maps, which were originally constructed in geographic latitude longitude projection, for all the factors and constraint was done in Erdas Imagine 9.2. Using rectification module of Erdas Imagine, Linear rubber sheet map transformation was used. Coordinates were assigned by using about 10 easily recognizable GCPs. Maps of all the criteria were geo-referenced to WGS84. First polynomial order and nearest neighborhood re-sampling method computes the new coordinates for output image. The projection of shape file of Punjab administrative boundary was already in WGS84 UTM zone 42N so all the geometrically rectified factor and constraint maps were then

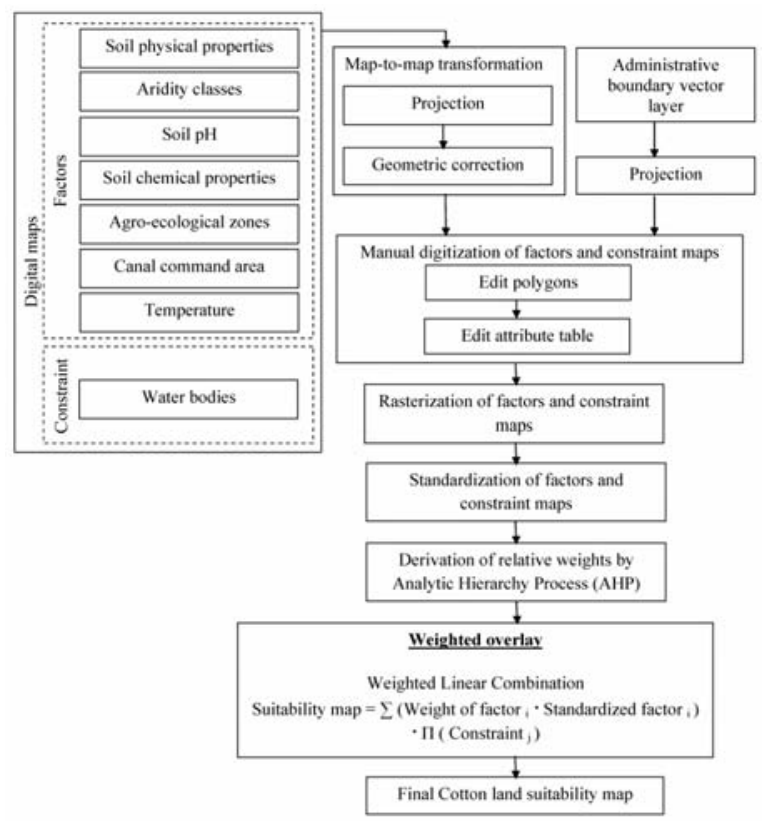

Fig. 1. The research procedure used in this study.
Table 2. Standardized criteria for the constraint and factors used in this work

\begin{tabular}{|c|c|}
\hline Layer & Standardization description of factors and constraint \\
\hline $\begin{array}{l}\text { Canal } \\
\text { command } \\
\text { area }\end{array}$ & $\begin{array}{l}\text { Suitable: Canal command area } \\
\text { Not suitable: } \\
\text { 1. Rivers } \\
\text { 2. Non-canal command area }\end{array}$ \\
\hline Soil pH & $\begin{array}{l}\text { Suitable: } 6.6-8.4 \\
\text { Not suitable: } \\
\text { 1. } 6.1-6.5 \\
2 .>8.4\end{array}$ \\
\hline $\begin{array}{l}\text { Soil } \\
\text { chemical } \\
\text { properties }\end{array}$ & $\begin{array}{l}\text { Suitable: } \\
\text { 1. Acid soils: slightly acid } \\
\text { 2. Neutral soils: non to slight calcareous } \\
\text { 3. Mildly alkaline soils: non to slight calcareous } \\
\text { 4. Mildly alkaline soils: moderately calcareous } \\
\text { 5. Mildly alkaline soils: strongly calcareous } \\
\text { 6. Moderately alkaline soils: non to slight calcareous } \\
\text { 7. Moderately alkaline soils: moderately calcareous } \\
\text { 8. Moderately alkaline soils: strongly calcareous } \\
\text { Not suitable: } \\
\text { 1. Salt affected soils: saline } \\
\text { 2. Salt affected soils: saline-sodic } \\
\text { 3. Salt affected soils: slight to strong saline-sodic } \\
\text { 4. Miscellaneous areas }\end{array}$ \\
\hline $\begin{array}{l}\text { Mean } \\
\text { maximum } \\
\text { annual } \\
\text { temperature }\end{array}$ & $\begin{array}{l}\text { Suitable: } 34^{\circ} \mathrm{C} \\
\text { Not suitable: } \\
1.26^{\circ} \mathrm{C} \\
2.28^{\circ} \mathrm{C} \\
3.30^{\circ} \mathrm{C} \\
4.32^{\circ} \mathrm{C}\end{array}$ \\
\hline $\begin{array}{l}\text { Soil } \\
\text { physical } \\
\text { properties }\end{array}$ & $\begin{array}{l}\text { Suitable: } \\
\text { 1. River plain and terraces: non calcareous loamy soil } \\
\text { 2. River plain and terraces: calcareous loamy soils } \\
\text { Not suitable: } \\
\text { 1. River plain and terraces: non calcareous clayey soil } \\
\text { 2. River plain and terraces: calcareous sandy soil, dune } \\
\text { 3. River plain and terraces: calcareous clayey soils } \\
\text { 4. River plain and terraces: salt affected soils } \\
\text { 5. Piedmont plains: non-calcareous loamy soils } \\
\text { 6. Piedmont plains: non-calcareous clayey soils } \\
\text { 7. Piedmont plains: calcareous sandy soils } \\
\text { 8. Piedmont plains: calcareous loamy soils } \\
\text { 9. Piedmont plains: calcareous clayey soils } \\
\text { 10. Piedmont plains: salt affected soils } \\
\text { 11. Loess and weathered rock plains } \\
\text { 12. Mountains and hills } \\
\text { 13. Seasonally flooded soils } \\
\text { 14. Sand dunes and sandy soils }\end{array}$ \\
\hline $\begin{array}{l}\text { Aridity } \\
\text { classes }\end{array}$ & $\begin{array}{l}\text { Suitable: } \\
\text { 1. Arid (Kharif, Rabi) } \\
\text { 2. Arid (Kharif), Hyper-arid (Rabi) } \\
\text { Not suitable: } \\
\text { 1. Humid } \\
\text { 2. Sub-humid } \\
\text { 3. Semi-arid }\end{array}$ \\
\hline $\begin{array}{l}\text { Agro- } \\
\text { ecological } \\
\text { zones }\end{array}$ & $\begin{array}{l}\text { Suitable: } \\
\text { 1. Irrigated plains: D.G. Khan irrigated } \\
\text { 2. Irrigated plains: cotton zone } \\
\text { Not suitable: } \\
\text { 1. Barani region: high rainfall } \\
\text { 2. Barani region: low rainfall } \\
\text { 3. Thal region: arid zone } \\
\text { 4. Thal region: irrigated zone } \\
\text { 5. Marginal land: Suleiman mountains } \\
\text { 6. Irrigated plains: central mixed zone } \\
\text { 7. Marginal land: Cholistan } \\
\text { 8. Irrigated plains: rice zone }\end{array}$ \\
\hline $\begin{array}{l}\text { River } \\
\text { constraint }\end{array}$ & $\begin{array}{l}\text { Suitable: Land } \\
\text { Not suitable: Rivers }\end{array}$ \\
\hline
\end{tabular}


re-projected to WGS84 UTM zone 42N using ArcGIS 10.2.2. In ArcGIS 10.2.2 all factors and constraint were then manually digitized using the projected shape file of Punjab administrative boundary with geometrically rectified maps as base maps. In this work, the used factors: canal command area (Fig. 2), soil $\mathrm{pH}$ ranges (Fig. 3), soil chemical properties classes (Fig. 4), mean maximum annual temperature (Fig. 5), soil physical properties classes (Fig. 6), aridity classes (Fig. 7), agroecological zones (Fig. 8), and constraint: Punjab rivers (Fig. 9), describe all the classes in a particular layer of the study area. For generating the standardized map for each parameter and the final aggregated land suitability map in Idrisi Selva, all the parameters should be in raster form. For this, rasterization was performed in Idrisi Selva with the resolution of $100 \times 100 \mathrm{~m}$.

The logic of aggregation demands that all the rasterized criteria be standardized to the same scale to make comparisons possible. Ranges of values that are not of interest are explicitly set to 0 while, the range of interest is set to 1 (Eastman, 2012). The re-class tool of Idrisi Selva was used to standardize the input criteria. Standardized

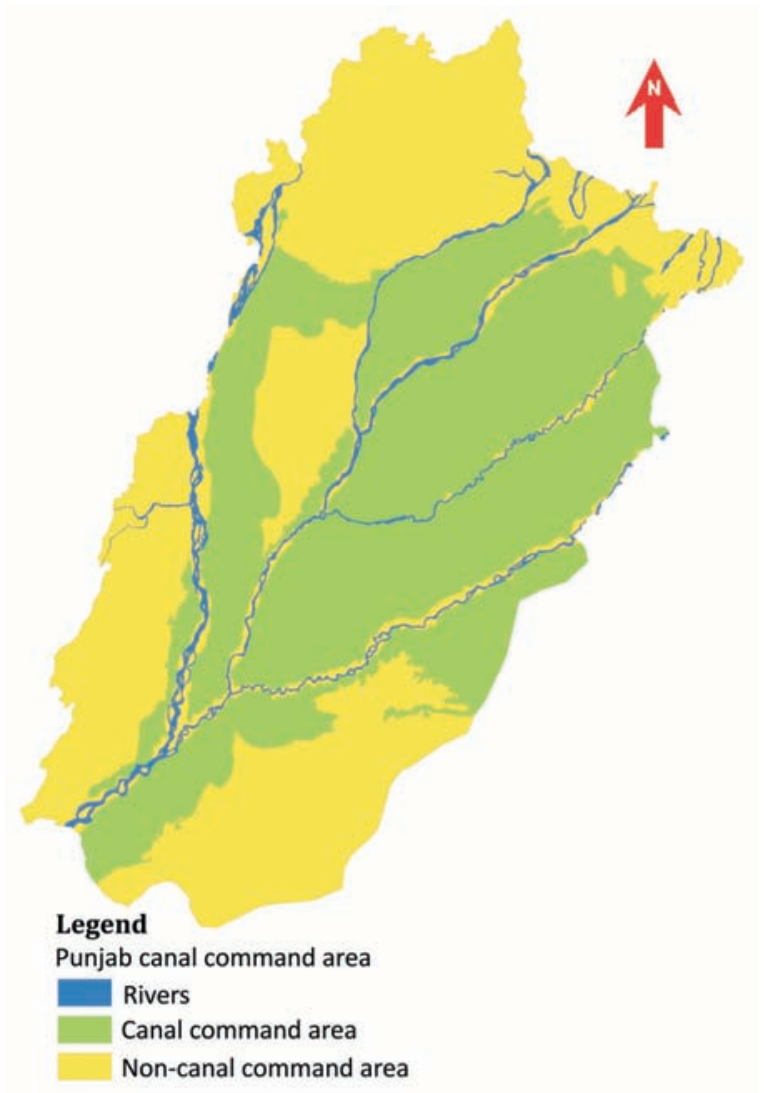

Fig. 2. Digitized map of Punjab canal command area. criteria (Table 2) describe suitability and non suitability for cotton cultivation (Arain et al., 2014). In this study, the standardized factors: canal command area (Fig. 10), soil $\mathrm{pH}$ ranges (Fig. 11), soil chemical properties classes (Fig. 12), mean maximum annual temperature (Fig. 13), soil physi-cal properties classes (Fig. 14), aridity classes (Fig. 15), agro-ecological zones (Fig. 16), and constraint: Punjab rivers (Fig. 17), describe only the suitable and not suitable class in a particular layer for cotton cultivation in the study area.

Analytic hierarchy process. In Idrisi Selva AHP method was used to derive a set of weights for all the standardized factors by utilizing PWCM with the principal Eigen vector of this matrix representing a best fit set of weights by Saaty's method. In the comparison matrix, two factors were compared at a time in terms of their importance on a scale from $1 / 9$ to 9 , where $1 / 9$ indicates that relative to the column factor, the row factor is less important; 9 indicates that in relation to the column factor, the row factor is more important (Eastman, 2012; Teknomo, 2006). After constructing comparison matrix, Eigen vectors were computed, which were the normalized

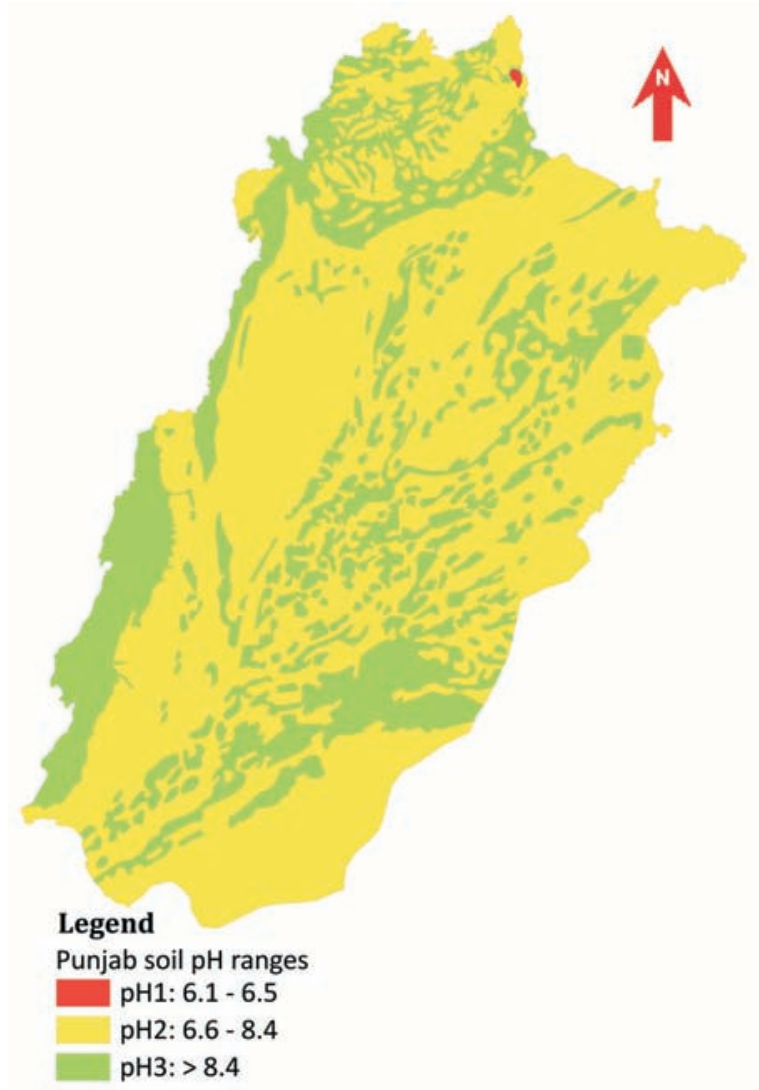

Fig. 3. Digitized map of Punjab soil pH. 
Table 3. Pairwise Comparison Matrix of all the factors relevant to cotton crop land suitability

\begin{tabular}{llllllll}
\hline \hline Factors & $\begin{array}{l}\text { Soil } \\
\mathrm{pH}\end{array}$ & $\begin{array}{l}\text { Canal } \\
\text { command } \\
\text { area }\end{array}$ & $\begin{array}{l}\text { Soil } \\
\text { chemical } \\
\text { properties }\end{array}$ & $\begin{array}{l}\text { Mean annual } \\
\text { maximum } \\
\text { temperature }\end{array}$ & $\begin{array}{l}\text { Soil } \\
\text { physical } \\
\text { properties }\end{array}$ & $\begin{array}{l}\text { Aridity } \\
\text { classes }\end{array}$ & $\begin{array}{l}\text { Agro- } \\
\text { ecological } \\
\text { zones }\end{array}$ \\
\hline Soil pH & 1 & - & - & - & - & - & - \\
Canal command area & $1 / 3$ & 1 & - & - & - & - & - \\
Soil chemical properties & 1 & 3 & 1 & - & - & - & - \\
Mean annual maximum temperature & 3 & 1 & 3 & 1 & - & - & - \\
Soil physical properties & 5 & 3 & 5 & 5 & 1 & - & - \\
Aridity classes & 7 & 7 & 3 & 3 & 1 & 1 & - \\
Agro-ecological zones & 9 & 7 & 5 & 5 & 3 & 1 & 1 \\
\hline \hline
\end{tabular}

Eigen vector of the matrix obtained by normalizing each column of the matrix. Since vectors are normalized, the elements in Eigen vector sum to 1. PWCM (Table 3) represent the relative importance of all the

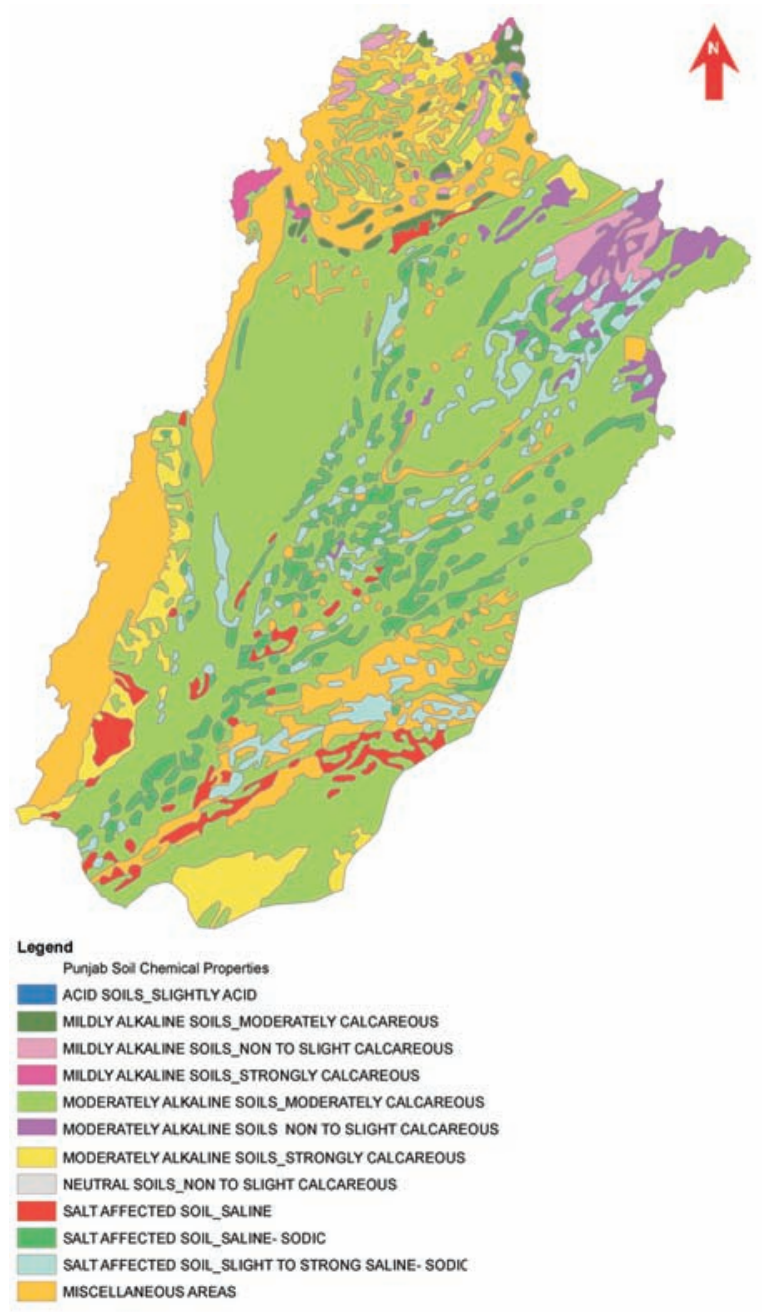

Fig. 4. Digitized map of Punjab soil chemical properties.
Table 4. Weights of all the factors used in the study

\begin{tabular}{ll}
\hline Factors & Weights \\
\hline Canal command area & 0.0397 \\
Soil pH & 0.0471 \\
Soil chemical properties & 0.0567 \\
Mean maximum annual temperature & 0.0804 \\
Soil physical properties & 0.2072 \\
Aridity classes & 0.2335 \\
Agro ecological zones & 0.3354 \\
\hline \hline
\end{tabular}

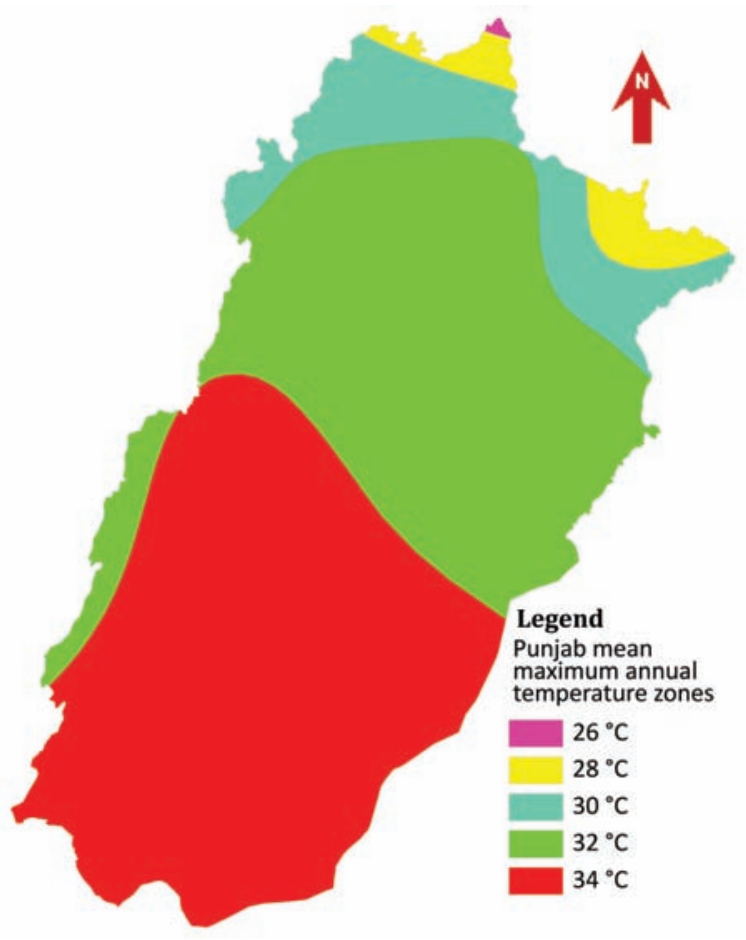

Fig. 5. Digitized map of Punjab mean maximum annual temperature. 


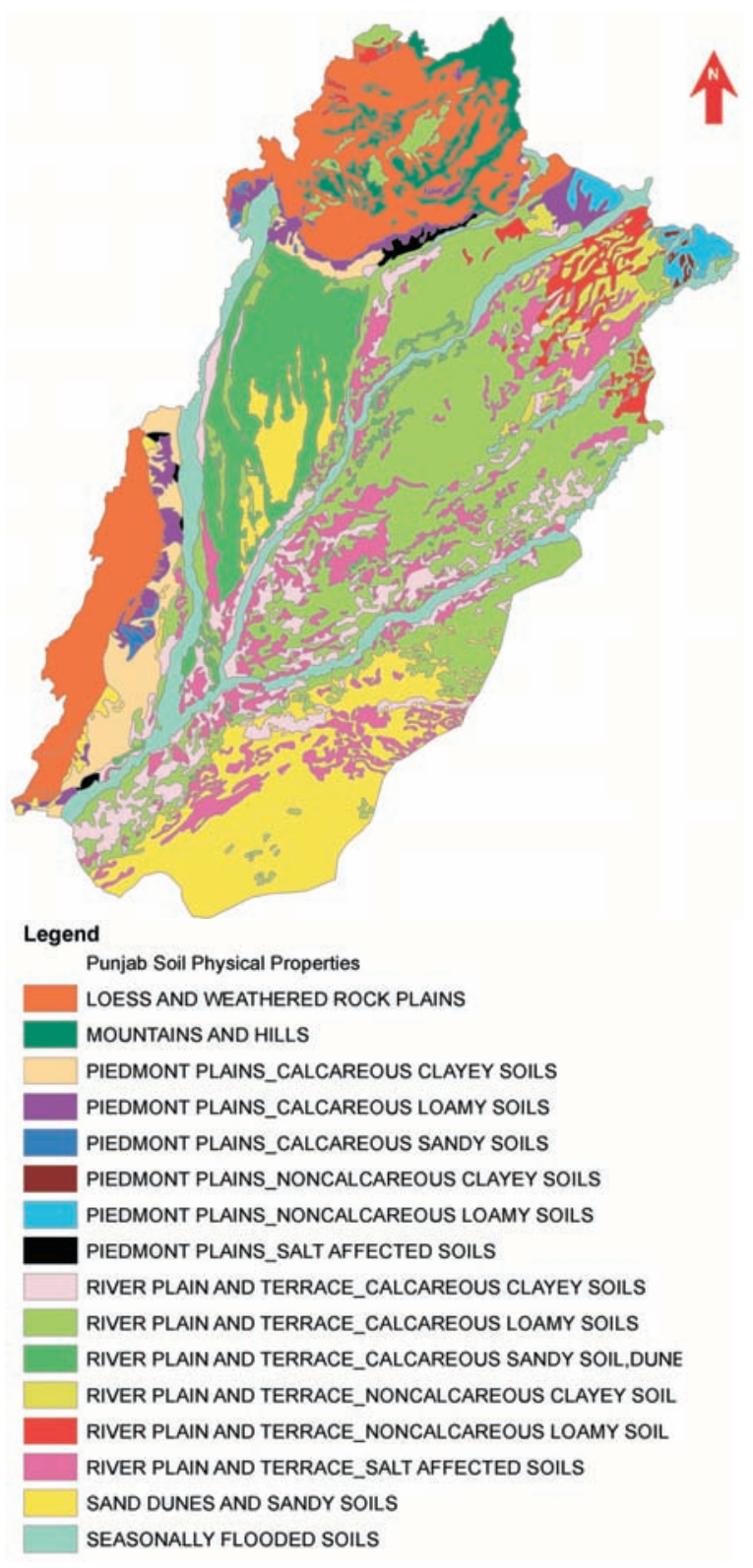

Fig. 6. Digitized map of Punjab soil physical properties.

factors involved in this study. The hierarchy of weights for all the factors (Table 4) was used for generating final land suitability map.

Weights are used to derive consistency ratio (CR) which indicates any inconsistency made in PWCM. If CR > 0.10 , then some pair-wise values need to be reconsidered until desired value of $\mathrm{CR}<0.10$ is reached (Eastman, 2012). The formula for consistency ratio (Kihoro et al., 2013) was described in equation 1 and 2 :

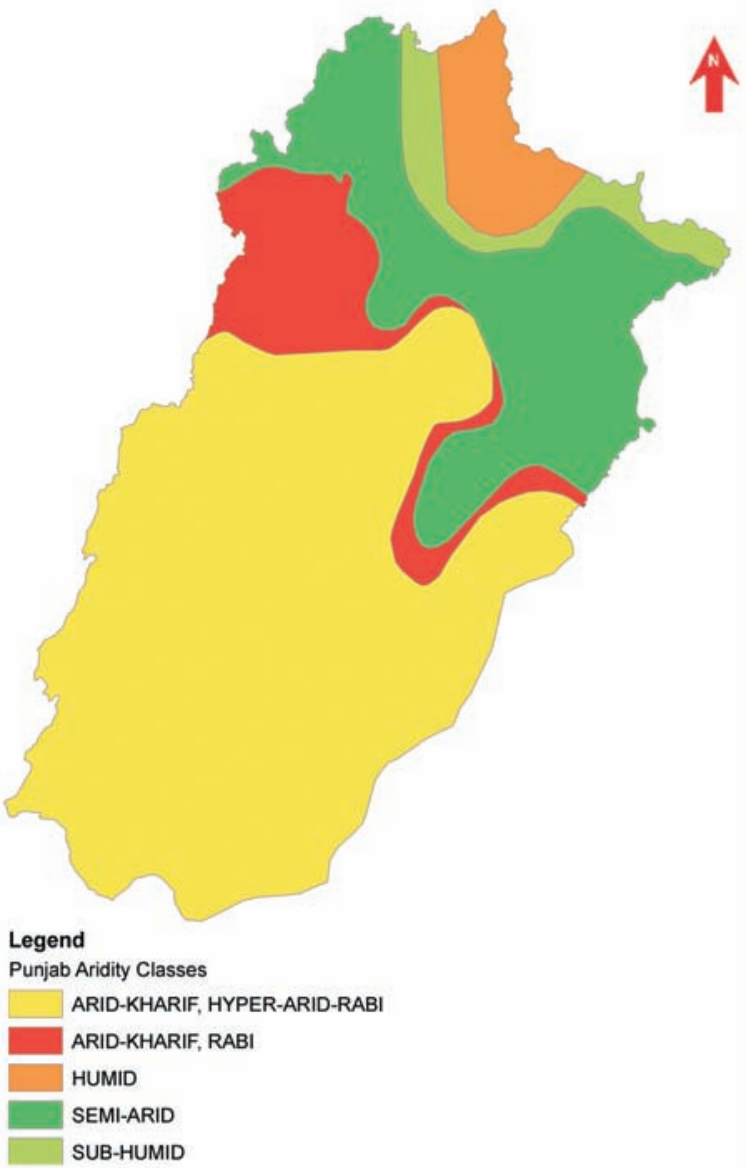

Fig. 7. Digitized map of Punjab aridity classes.

$$
\begin{aligned}
& \mathrm{CI}=\frac{\left(\lambda_{\max }-\mathrm{n}\right)}{(\mathrm{n}-1)} \\
& \mathrm{CR}=\frac{\mathrm{CI}}{\mathrm{RI}} \ldots \ldots . . .
\end{aligned}
$$

where:

$\lambda_{\max }=$ maximum Eigen value, $\mathrm{CI}=$ Consistency Index, $\mathrm{CR}=$ Consistency Ratio, $\mathrm{RI}=$ Random Index and $\mathrm{n}=$ number of criteria in each PWCM. This step was performed in Idrisi Selva. In this work, Eigen vector has acceptable consistency ratio of 0.09 .

GIS based MCE is concerned with the allocation of land to suit a specific objective on the basis of variety of attributes that the selected areas should possess. In MCE, each standardized factor was combined by weighted linear combination that is, each factor was multiplied by a weight, with results being summed up, which was then multiplied by the product of constraints. The final image was measure of aggregated suitability 


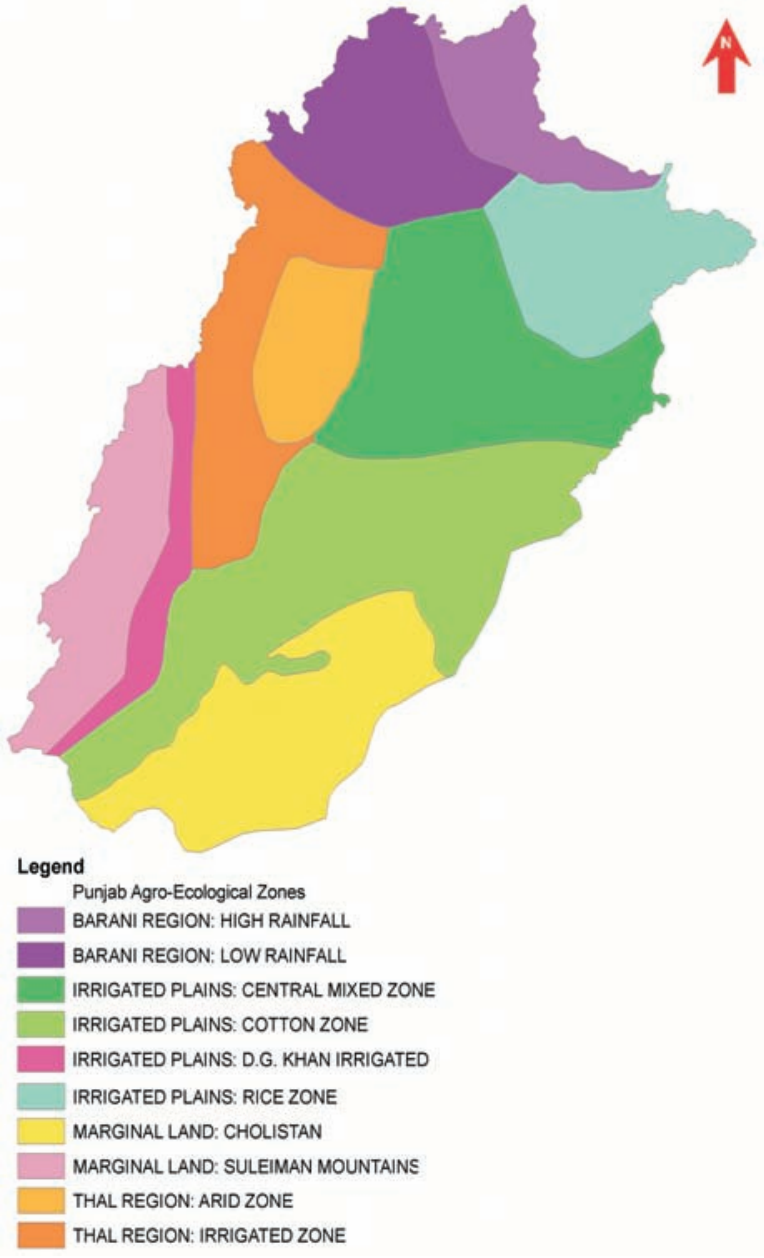

Fig. 8. Digitized map of Punjab agro-ecological zones.

for non-constrained locations (Fig. 18). The formula for WLC (Eastman, 1999) is given in equation 3:

$$
\mathrm{s}=\sum \mathrm{w}_{\mathrm{i}} \mathrm{x}_{\mathrm{i}} \cdot \prod \mathrm{c}_{\mathrm{j}}
$$

where:

$\mathrm{S}=$ the composite suitability score, $\mathrm{w}_{\mathrm{i}}=$ weight of a factor, $\mathrm{x}_{\mathrm{i}}=$ factor, $\mathrm{c}_{\mathrm{j}}=$ constraint,$\sum=$ the sum of weighted factors, and $\Pi=$ product of constraints.

\section{Results and Discussion}

The final suitability map (Fig. 19) generated by GIS based AHP modeling technique for cotton cultivation potential sites in Punjab by using decision support tool of multi criteria. Number of hectares suitable for cotton

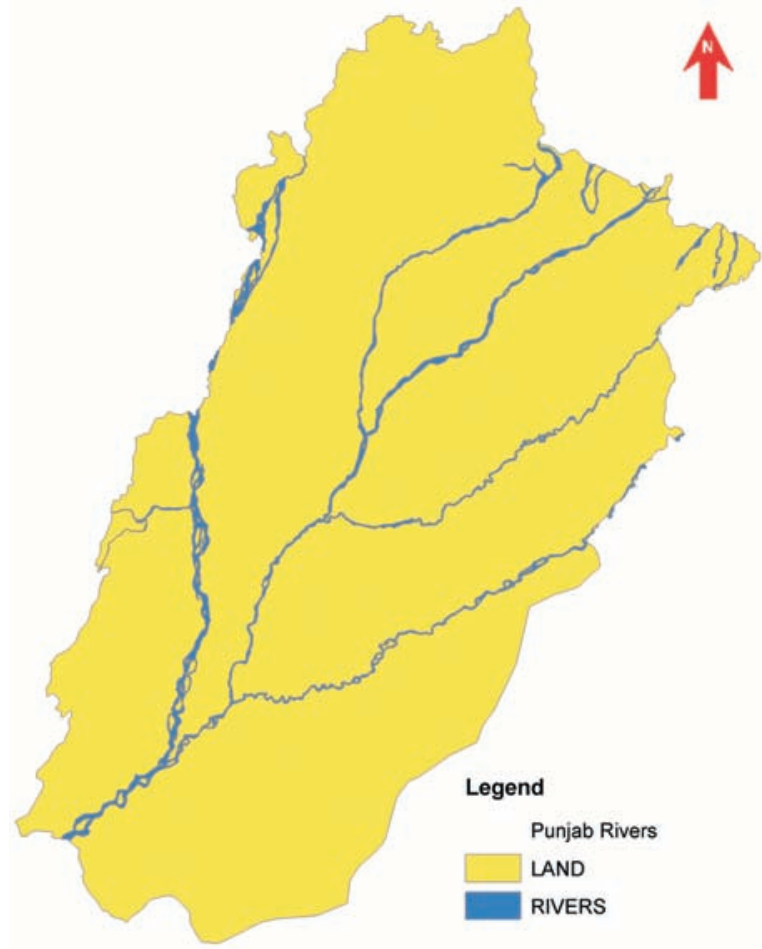

Fig. 9. Digitized map of Punjab river constraint.

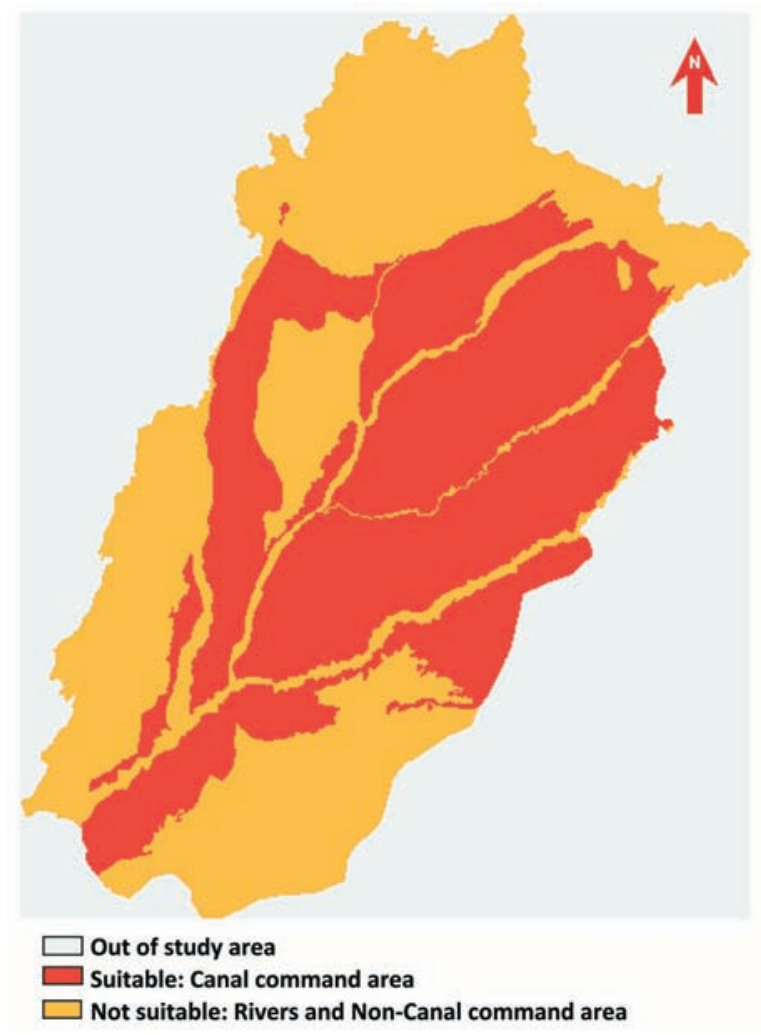

Fig. 10. Standardized factor map for Punjab canal command area. 


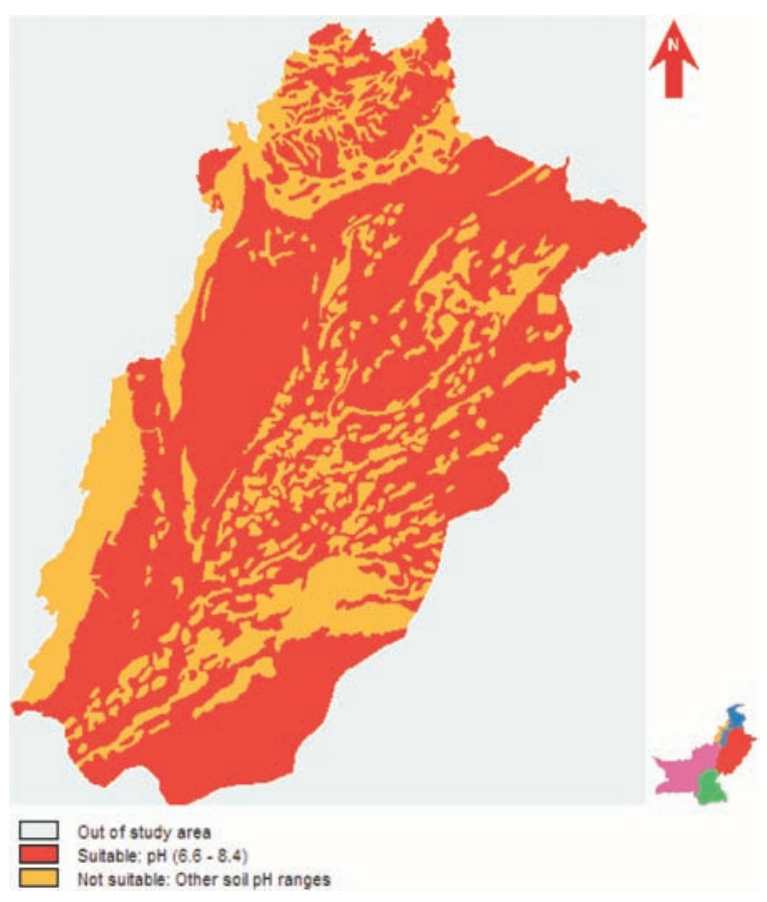

Fig. 11. Standardized factor map of Punjab soil $\mathrm{pH}$.

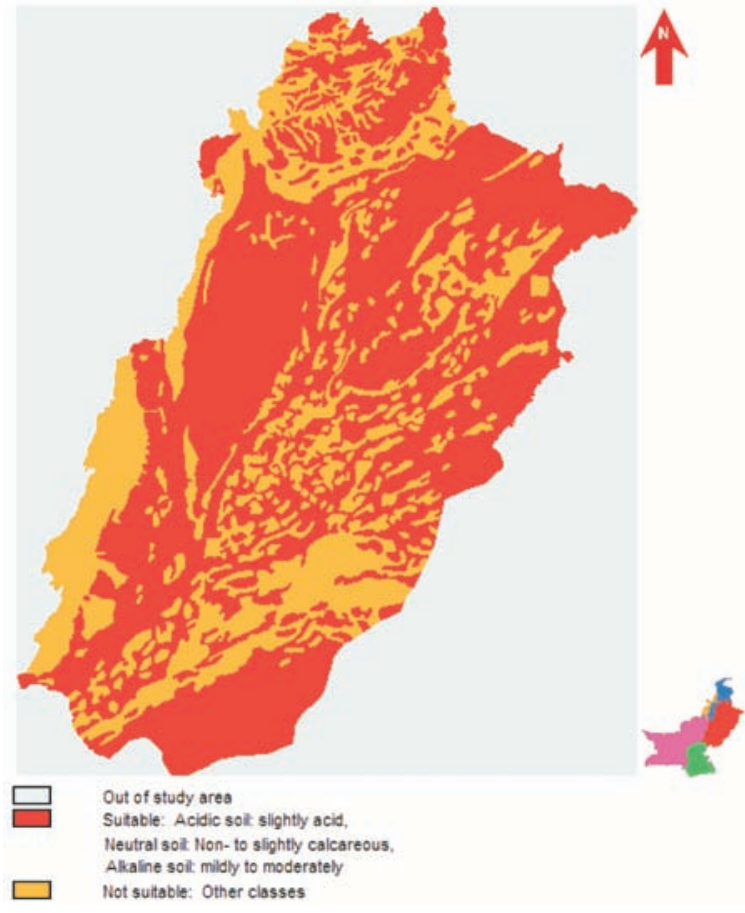

Fig. 12. Standardized factor map of Punjab soil chemical properties.

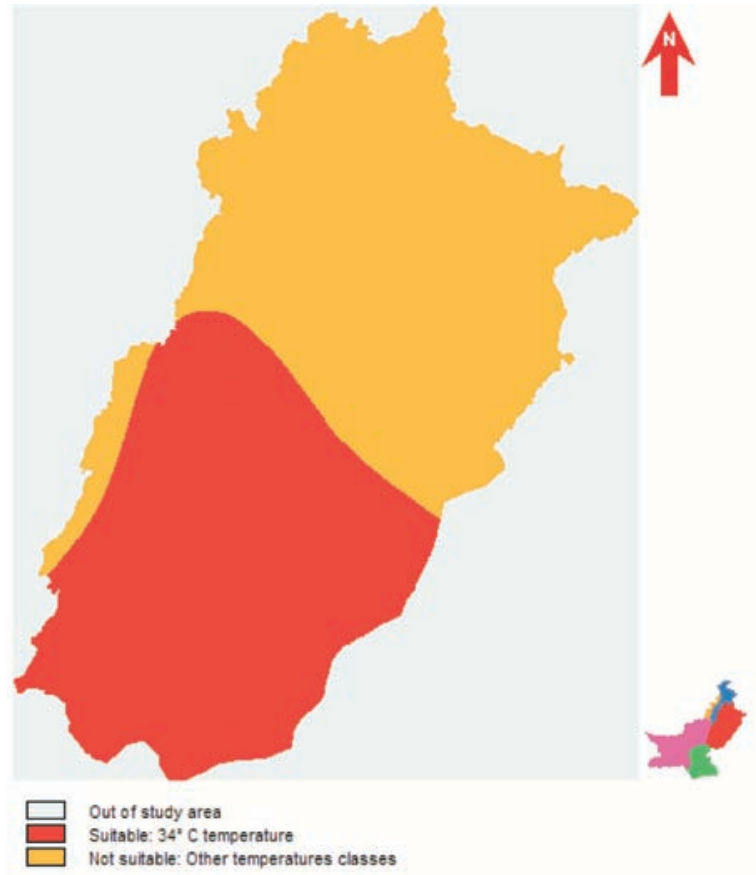

Fig. 13. Standardized factor map of Punjab mean maximum annual temperature.

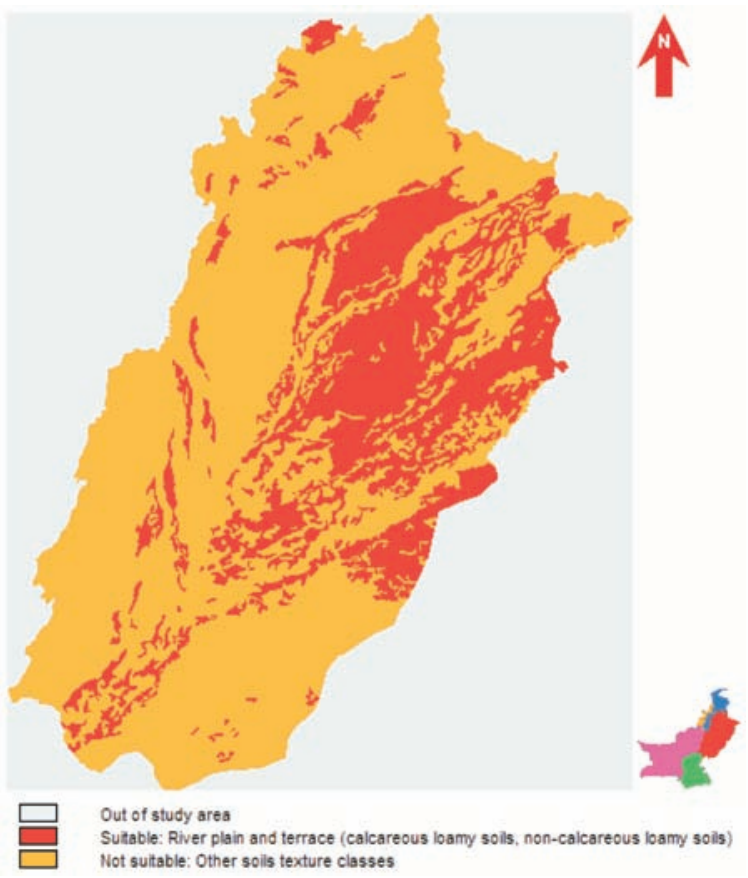

Fig. 14. Standardized factor map of Punjab soil physical properties. 
Table 5. Summary of statistical information by GIS based AHP model for cotton land suitability in Punjab, Pakistan

\begin{tabular}{llll}
\hline \hline Statistics & \multicolumn{2}{c}{ Area } & Production (Bales) \\
\cline { 2 - 3 } & Area (hectare) & Percentage (\%) & \\
\hline Suitable land & 6141259.4685409 & 31 & 27021541.66157996 \\
Not suitable land & 13811985.0537708 & 69 & 0 \\
Land under cultivation (2011-2012) & 2533000 & 13 & 11129000 \\
Potential increase by suitability map & 3608259.4685409 & 18 & 15892541.66157996 \\
\hline \hline
\end{tabular}

cultivation was 6141259.4685409 hectares with production capability 27021541.66157996 bales and area not suitable for cotton cultivation was 13811985.0537708 hectares. Of the study area, 31\% represents suitable area and $69 \%$ represents not suitable area (Table 5) for cotton cultivation.

According to Punjab Development Statistics (Rafique, 2013), area sown under cotton for 2012 was 2533000 hectares with production for the year 2011-2012 was 11129000 bales. According to this statistical report, existing cropland under cultivation covers $13 \%$ while area not under cultivation was $87 \%$ of the study area.

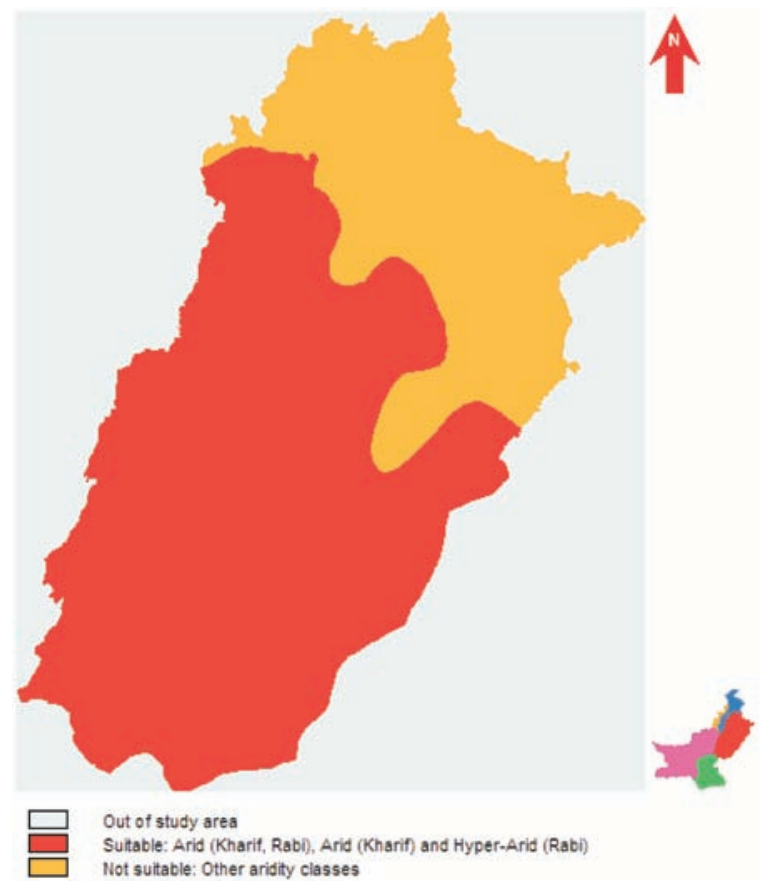

Fig. 15. Standardized factor map of Punjab aridity classes.
The final cotton land suitability map represents $18 \%$ increase in suitable area for cotton cultivation with an increased potential in production of 15892541.66157996 bales were recorded.

According to Punjab Development Statistics (Rafique, 2013), highly suitable districts for cotton cultivation were Rahim Yar Khan, Bahawalpur, Bahawalnagar, Multan, Dera Ghazi Khan, Muzaffargarh, Vehari, Khanewal, Sahiwal, Lodhran, and Rajanpur. Final cotton land suitability map indicates that the districts with large extent of suitability were Bahawalnagar, Bahawalpur, Chiniot, Dera Ghazi Khan, Faisalabad, Jhang, Khanewal,

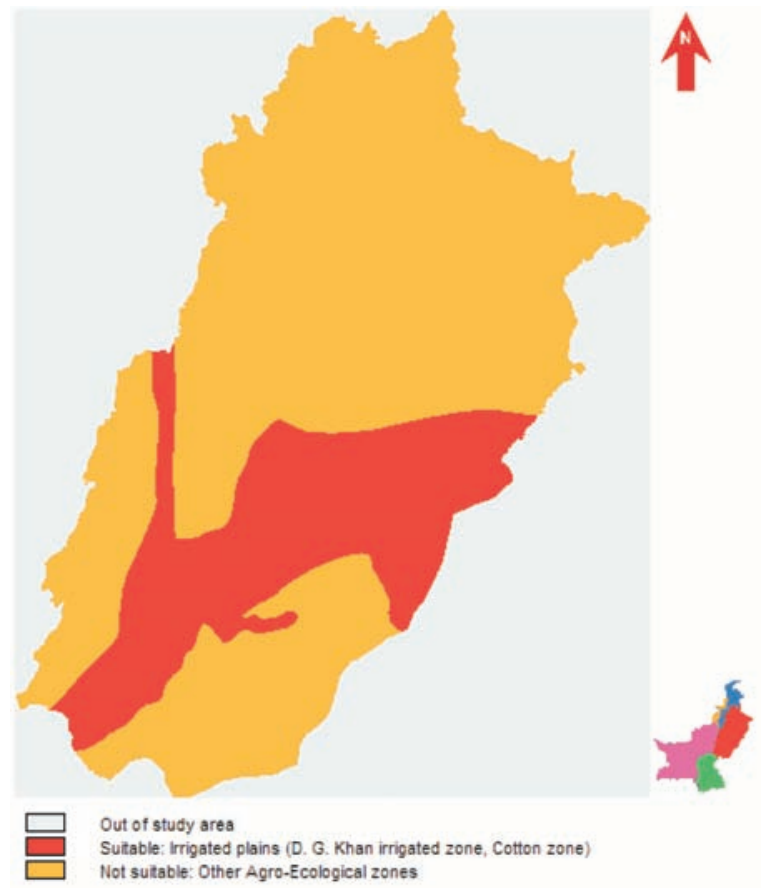

Fig. 16. Standardized factor map of Punjab agroecological zones. 


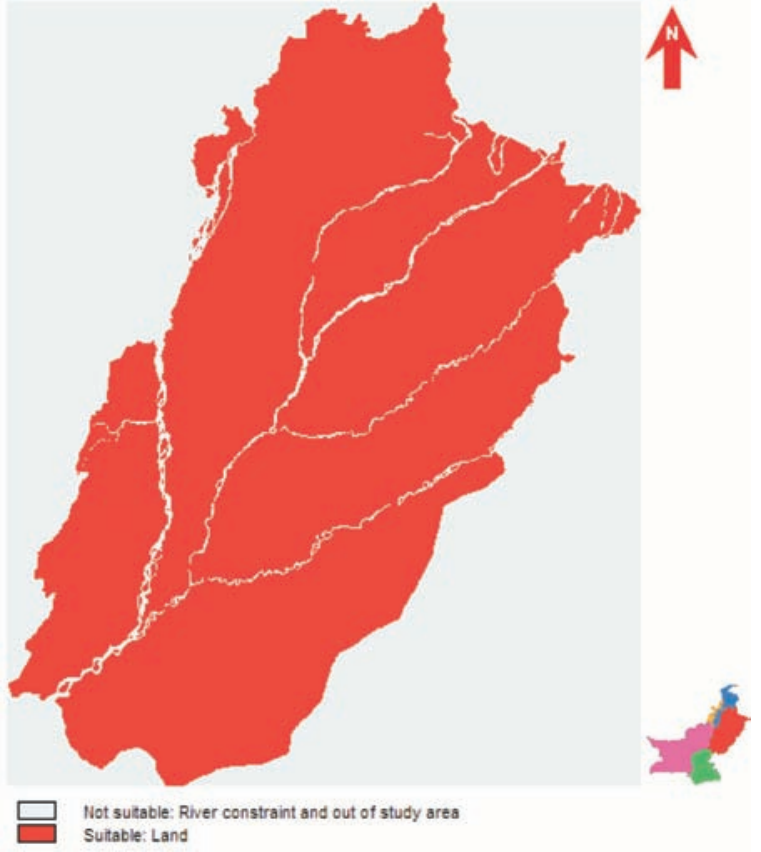

Fig. 17. Standardized constraint map of Punjab rivers.

Lodhran, Multan, Muzaffargarh, Okara, Pakpattan, Rahim Yar Khan, Rajanpur, Sahiwal, Toba Tek Singh, and Vehari. Districts with less extent suitable area were Bhakkar, Chakwal, Khushab, Layyah, Mianwali, and Sargodha. Districts not suitable for cotton cultivation were Attock, Gujranwala, Gujrat, Hafizabad, Jhelum, Kasur, Lahore, Mandi Bahauddin, Nankana Sahib, Narowal, Rawalpindi, Sheikhupura, and Sialkot.

The final suitability map (Fig. 19) shows that the agro ecological zone, aridity classes, soil physical properties and temperature zones comprise the major part of the cotton suitable land in this analysis. There are several other crops grown under the cotton suitable areas that necessitate their land suitability evaluation in order to get better yields by optimally utilizing the present resources. The areas which are not suitable for cotton cultivation may be suitable for any other crop and excellent results can be obtained by better management in terms of millions of bales. This will eventually give boost to economy of Pakistan, which also supports the textile industrial sector.

The final land suitability map for cotton cultivation is also in conformity with the findings of IWMI research report (Cai et al., 2010); Punjab districts cotton production (SUPARCO, 2012); major and minor cotton crop areas (USDA, 2014); cotton production regions (FAO, 2004) who concluded the sites suitable for cotton cultivation in Punjab, Pakistan.

\section{Conclusion}

For decision makers to select certain crop land suitability is a complicated issue especially when based on environmental factors. The GIS based MCE using AHP procedure involves the utilization of geographical data, the decision maker preferences, manipulation of data, and preference according to specific decision rules. The model implemented in this study, demonstrated a rational and objective approach to make decisions in agricultural applications in Punjab. MCE method was adequate to integrate databases required for different kinds of environmental variables in a GIS context.

In this study, application of GIS technique to identify suitable areas for cotton crop in Punjab, Pakistan was successful. The results obtained from this study, indicate that the use of GIS and application of MCE using AHP could provide a superior guide map for farmers and decision makers at local level to select the appropriate cultivation sites, crop management and diversification operations to achieve better agricultural production. The approach has been used in some studies in other countries. This study clearly brought out the distribution of cotton derived from the evaluation of environmental variables in GIS context.

Additionally, the result of this study could be useful for other investigators who could use these results for diverse studies. This study has been done considering soil physical and chemical properties, temperature, water resources, aridity, and agro-ecological zones that affected the suitability of cotton cultivation. Therefore, it gives primary result.

The common thread in mapping cotton cultivation suitability is to utilize correct environmental variables to achieve greater accuracy. To accomplish this, the study has focused deeply on those environmental variables that are worth mentioning for cotton cultivation and accurate enough to provide perfect suitability map. 


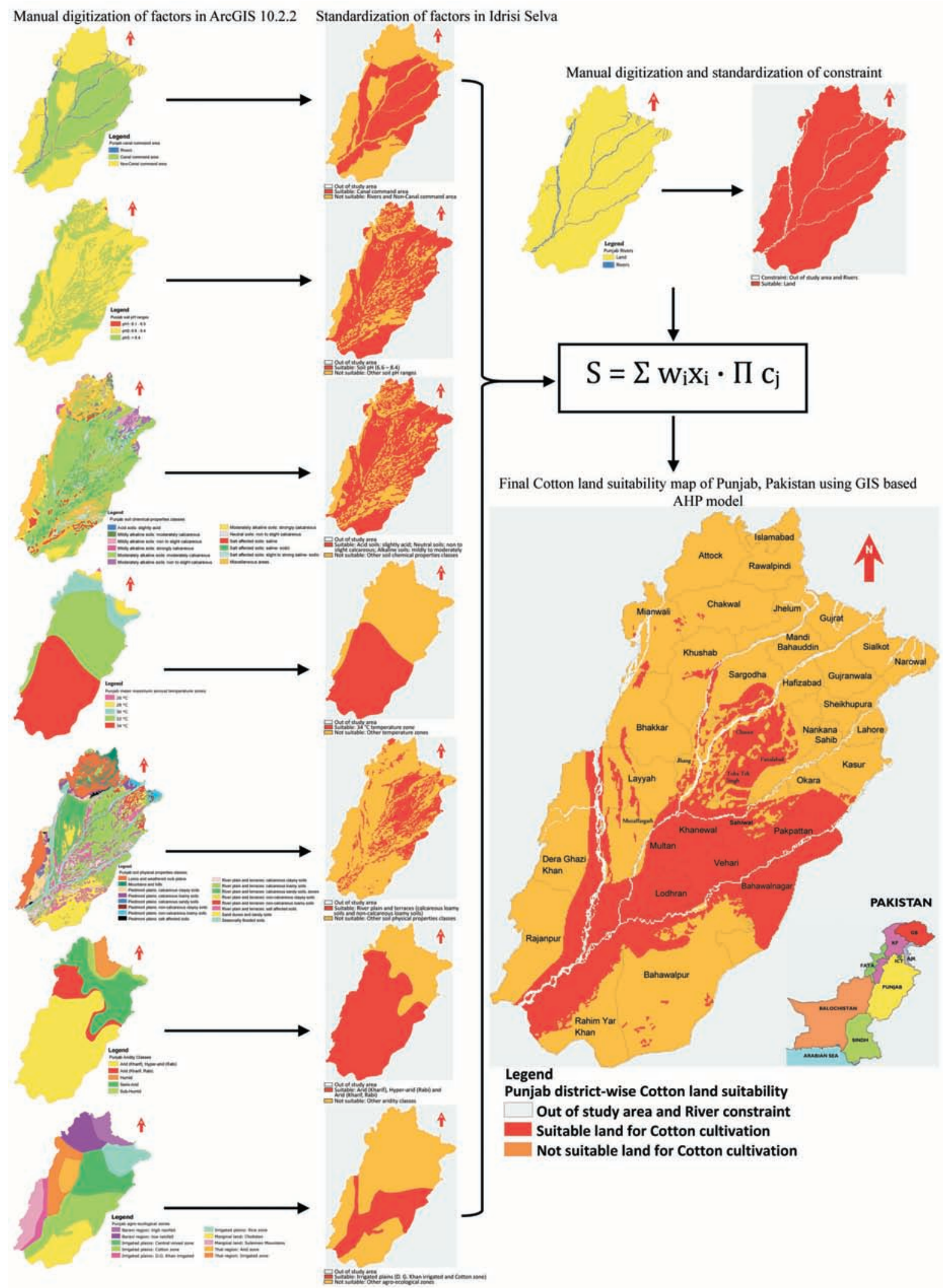

Fig. 18. The process of combining criteria maps for cotton land suitability in Punjab, Pakistan, using GIS based AHP model. 


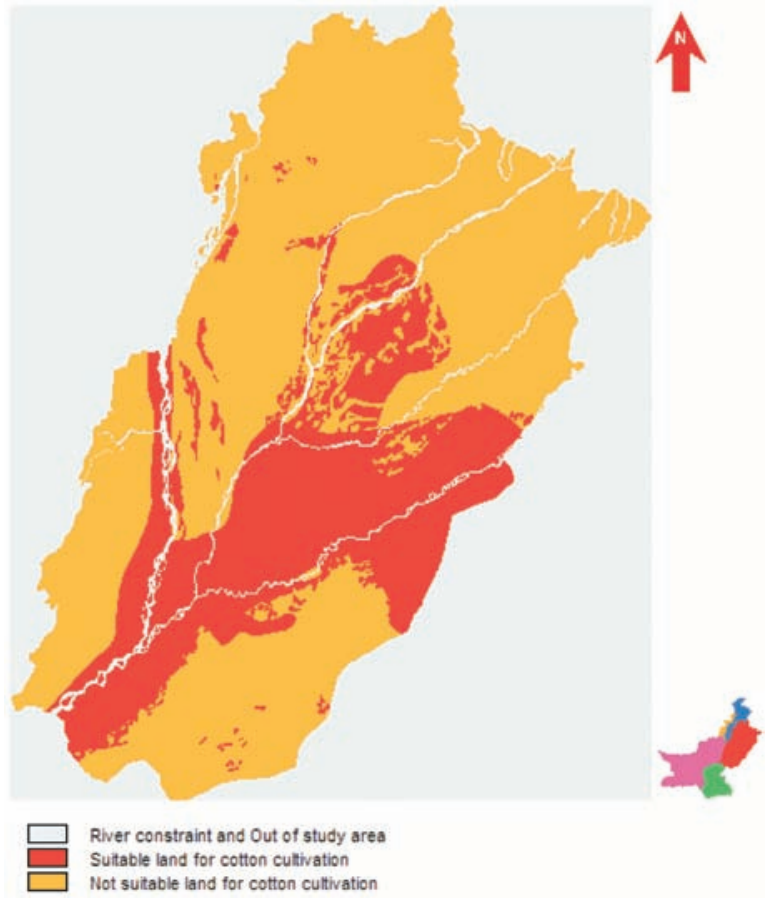

Fig. 19. Land suitability map for Cotton cultivation in Punjab, Pakistan, using GIS based AHP model.

\section{References}

Akinci, H., Ozalp, A.Y., Turgut, B. 2013. Agricultural land use suitability analysis using GIS and AHP technique. Computers and Electronics in Agriculture, 97: 71-82.

Arain, M.A., Ali, Q.M., Ali, M.I.K. 2014. Land suitability criteria table, Pakistan Agricultural Research Council (PARC), Karachi Centre, University of Karachi, Karachi, Pakistan.

Brabben, T. 2000. International Programme for Technology and Research in Irrigation and Drainage, Pakistan. In: Proceedings of Roundtable Meeting, pp. 1-152, Lahore, Pakistan.

Cai, X., Sharma, B.R., Matin, M.A., Sharma, D., Gunasinghe, S. 2010. An Assessment of Crop Water Productivity in the Indus and Ganges River Basins: Current Status and Scope for Improvement, 30 pp., International Water Management Institute (IWMI) Research Report 140, Colombo, Sri Lanka.

Eastman, J.R. 2012. IDRISI Selva Tutorial Manual Version 17, IDRISI Production, Clark University, Worcester, USA.
Eastman, J.R. 1999. Multi-criteria evaluation and GIS. In: Geographical Information Systems: Principles and Technical Issues, P. A. Longley, M. F. Goodchild, D. J. Maguire and D. W. Rhind (eds.), vol. 1, pp. 493-502, $2^{\text {nd }}$ edition, John Wiley \& Sons, Inc., USA.

FAO, 2004. Fertilizer Use by Crop in Pakistan. Land and Plant Nutrition Management Service, Land and Water Development Division, Food and Agriculture Organization of the United Nations, Rome, Italy.

FAS-USDA, 2016. Cotton: World Markets and Trade, Foreign Agricultural Service, U.S. Department of Agriculture, Washington, D.C., USA.

Hussain, T. 2014. A review of cotton yarn exports from Pakistan in 2013. Retrieved July 10, 2014 from http://www.fibre2fashion.com/industryarticle/52/5183/a-review-of-cotton-yarn-exportsfrom-pakistan-in-20132.asp.

ICIMOD, 2008. Mean Maximum Annual Temperature. Retrieved June 30, 2014 from http://geoportal. icimod.org/DataExplorer/search.html\#.

Iqbal, F., Mehdi, M.R. 2008. Detection of suitable soils for zero-till wheat cultivation in Pakistan using GITs. In: Proceeding of International Workshop on Earth, Observation and Remote Sensing Applications, IEEE International, pp. 1-9, Beijing, China.

Joshua, J.K., Anyanwu, N.C., Ahmed, A.J. 2013. Land suitability analysis for agricultural planning using GIS and multi criteria decision analysis approach in greater Karu urban area, Nasarawa state-Nigeria. African Journal of Agricultural Science and Technology Studies, 2: 14-23.

Khoi, D.D., Murayama, Y. 2010. Delineation of suitable cropland areas using a GIS based multi-criteria evaluation approach in the Tam Dao National Park Region, Vietnam. Sustainability, 2: 2024-2043.

Kihoro, J., Bosco, N.J., Murage, H. 2013. Suitability analysis for rice growing sites using a multicriteria evaluation and GIS approach in great Mwea region, Kenya. Springer Plus, 2: 1-9.

Malczewski, J. 2004. GIS-based land-use suitability analysis: A critical overview. Progress in Planning, 62: 3-65.

Panagos, P., Jones, A., Bosco, C., Kumar, S.P. 2011. European digital archive on soil maps (EuDASM): Preserving important soil data for public free access. International Journal of Digital Earth, 4: 434-443.

PARC, 2007. Agricultural Maps of Pakistan, Pakistan Agricultural Research Council (PARC). Retrieved 
May 17, 2014 from http://old.parc.gov.pk/agromaps. html.

PCO, 2013. Administrative Boundary Data, Pakistan Census Organisation (PCO). Retrieved May 10, 2014 from http://www.pakresponse.info/MapData Center/GISData.aspx.

Perveen, S., Arsalan, M.H., Siddiqui, M.F., Khan, I.A., Anjum, S., Abid, M. 2013. GIS-based multi-criteria model for cotton crop land suitability: A perspective from Sindh province of Pakistan. Federal Urdu University of Arts, Sciences \& Technology Journal of Biology, 3: 31-37.

Rafique, C.S. 2013. Punjab Development Statistics 2013, Bureau of Statistics Government of the Punjab, Lahore, Pakistan.

Saif, U. 2014. About Punjab, Punjab Portal. Retrieved July 12, 2014 from http://www.punjab.gov.pk/ about punjab.

Shafiq-ur-Rehman, M. 2015. Cotton and Products Annual,
Gain Report, U.S. Department of Agriculture, Foreign Agricultural Service, Islamabad, Pakistan. SUPARCO, 2012. Punjab CRS: Base Line Survey, Pakistan Space and Upper Atmosphere Research Commission, Government of Punjab Publication, Pakistan.

Teknomo, K. 2006. Analytic Hierarchy Process (AHP) tutorial. Retrieved July 10, 2014 from http://people. revoledu.com/kardi/tutorial/AHP/.

USDA, 2014. Pakistan: Cotton, United States Department of Agriculture. Retrieved July 10, 2014 from http://www.usda.gov/oce/weather/pubs/ Other/MWCACP/Graphs/Pakistan/Pakistan_Cott on.pdf.

Waqar, M.M., Rehman, F., Ikram, M. 2013. Land suitability assessment for rice crop using geospatial techniques. In: IEEE International, Geoscience and Remote Sensing Symposium (IGRASS), 2013, pp. 2844-2847, Melbourne, VIC, Australia. 